\title{
Stage II Renal Cell Cancer AJCC v6
}

National Cancer Institute

\section{Source}

National Cancer Institute. Stage II Renal Cell Cancer A/CC v6. NCI Thesaurus. Code C7824.

Stage II includes: T2, N0, M0. T2: Tumor more than $7 \mathrm{~cm}$ in greatest dimension limited to the kidney. NO: No regional lymph node metastases. MO: No distant metastasis. (AJCC 6th Ed.) - 2003 